\title{
PROFIT EFFICIENCY AMONG CATFISH FARMERS IN BENUE STATE, NIGERIA
}

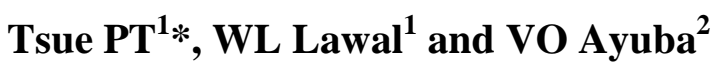

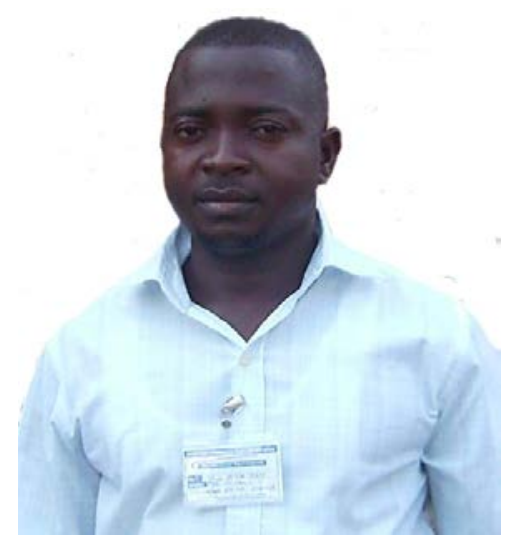

Peter Terfa Tsue

*Corresponding author email: pettsue@yahoo.com

${ }^{1}$ Department of Agricultural Economics, University of Agriculture, Makurdi, Benue State, Nigeria.

${ }^{2}$ Department of Fisheries, University of Agriculture, Makurdi Benue State, Nigeria. 


\section{ABSTRACT}

The study examined profit efficiency among catfish farmers in Benue State of Nigeria using a stochastic profit frontier approach. A multi-stage sampling technique was used to collect data from 143 catfish farmers through a well structured questionnaire. The study used a Cobb-Douglas stochastic profit frontier function to analyze the data and was estimated using a computer software, FRONTIER 4.1 version. The estimated elasticity parameters of variables with respect to gross profit of catfish farmers revealed the significance of all the independent variables included in the stochastic profit function. However, the number of ponds $(-0.02)$, cost of feed $(-0.30)$, cost of fingerlings (-0.11) and cost of hired labour (-0.004) had an inverse relationship with the profit of farmers with cost of feed being the most important variable decreasing the profit of farmers in the study area. The negative elasticity of number of ponds with respect to farmers' profit was likely due to under-utilization of ponds capacity. The result further indicated that the kilogramme of catfish produced (elasticity of 1.43) was the most important variable determining profit in catfish farming in the study area. Analysis of profit efficiency revealed a varied (23-99\%) profit efficiency of the farmers with a mean value of 0.84 . This implies that the farmers were able to obtain a little above 80 percent of their potential profit from a unit mix of inputs. This means that about 16 percent of the profit is lost due to inefficiency of management. Thus, in the short run there is scope for increasing profit from catfish production by 16 percent by adopting the technology and the techniques used by the 'best practiced' catfish farmers. Analysis of the factors influencing profit efficiency revealed that while age of famers, farming experience and duration of culture positively influenced profit efficiency, years of education, off-catfish-farm income, and training negatively influenced profit efficiency. The policy implication of these findings is that profit inefficiency in catfish production can be reduced significantly overtime as the farmers get more experienced and a more conducive environment is created, to encourage more aged farmers to be involved in catfish production in a bid to alleviate poverty and food insecurity in the state and the country at large.

Key words: Profit Efficiency, Catfish, Stochastic Frontier 


\section{INTRODUCTION}

Aquaculture is an underwater agricultural production of fish species in which production cycles such as breeding, feeding, cultivation and protection are virtually controlled by humans in contrast to capture fishery where the wild stocks of fish are harvested. The practice is regarded as being uniquely placed to reverse declining supplies from capture fisheries. The activity has a notable potential for new livelihood opportunities providing the mechanism for lower priced fish, enhanced nutritional security and employment for both rural and urban communities. In Nigeria, the most commonly cultured fish species include catfish (Clarias gariepinus, the imported $C$. lazera, Heterobrachus spp, and the imported C. hollandica ), tilapia and carp. Many fish farms in Nigeria focus on catfish, as they can have a market value of two to three times that of tilapia [1]. The African catfish from a biological perspective is said to be one of the most ideal aquaculture species in the world because it thrives in diverse environments. It can also survive on natural food or artificial food, which it accepts readily in captivity. It can be cultured in different culture systems such as ponds, cages, tanks, water re-circulatory system and whether through intensive or extensive fish culture system. Besides, catfish grows fairly fast and can be cross-bred to enhance certain favourable traits such as better body conformation (smaller head, more flesh), more hardiness, higher fecundity, improved survival of fry, and adaptation to supplementary feed. For example, catfish which is naturally a bottom feeder, now readily accepts floating feed, which makes it easy to observe the fish for behavioural patterns, growth rate and disease outbreak [2].

Fish production in Nigeria is not only important as a source of rich protein, but it also can be used to bring about institutional changes. These changes can offer access to production assets and resources which can help to empower the poor and directly promote their livelihoods. The increase in fish consumption as a good source of protein and its cultural and religious acceptability are an indication that catfish culturists must live up to expectation of meeting the local demand. To achieve this objective, efforts must be taken to examine the productive efficiency of the catfish culturists in the country, using profit efficiency that is based on perfect competitive market.

Computing profit efficiency, therefore, constitutes a more important source of information for policy makers than the partial vision offered by analyzing cost efficiency. The estimation of a frontier profit function captures firm level production specialization, thus allowing the higher revenues reserved by the firm that produced differentiated or higher quality output to compensate for a higher cost incurred [3].

Considerable efforts have been directed at examining productive efficiency of fish farmers in Nigeria that is exclusively focused on technical efficiency of fish farmers in general $[4,5,6,7,8]$ and profitability of fish farming $[9,10]$. However, little or no attention has been given to measuring profit efficiency of catfish farmers in Benue State, even when prices of input and output are known. The physical productivity considerations (technical efficiency) are important improvements in production efficiency, but profit efficiency will lead to greater benefits to catfish farmers in the 
study area. It is against this backdrop that this article was embarked upon with a view to proffering answers to research questions that could be faced by practising and prospective catfish farmers, with the following objectives addressed:

i. To analyze profit efficiency among catfish farmers in Benue State;

ii. To identify producer and farm-specific characteristics that explain variations in efficiency.

\section{MATERIALS AND METHODS}

\section{The Study Area}

This study was conducted in Benue State, Nigeria because scanty information exists on catfish production in the State. The State derives its name from River Benue, the largest river in Nigeria and it lies between longitude $6^{0} 35^{\prime}$ and $8^{0} 10^{\prime} \mathrm{E}$ of the Greenwich and latitude $6^{0} 30^{\prime} \mathrm{N}$ and $8^{0} 10^{\prime} \mathrm{N}$ of the equator, at an elevation of 97 meters above sea level in the Southern Guinea Savannah agro-ecological zone. The State is located in the North-central zone of Nigeria and is referred to as the "Food Basket of the Nation" due to the fact that it is a major producer of food in Nigeria. Major crops produced in the State include: cassava, yam, rice, benniseed, maize, sweet potatoes, millet, soybeans and a wide range of tree crops like mango, citrus, oil palm and bananas. Others include livestock production and fishing. The State is administratively divided into three zones namely Zone A (Eastern zone), Zone B (Northern zone), Zone C (central zone), and has twenty three (23) local government areas.

\section{Data collection}

The population for this study comprised all catfish farmers in Benue State, which were 245 in number and consist of 20, 159 and 66 catfish farmers in zones A, B and $\mathrm{C}$, respectively [11]. A multi-stage stratified sampling technique was used to select 158 catfish farmers through a questionnaire. Zones B and C were purposively selected for the study based on higher population of catfish culturists in the areas. Furthermore, a proportional sample of 70 percent of the catfish farmers were selected from each of the zones earlier selected to give a total of 158 catfish farmers sampled for the study. However, only 143 of 158 returned questionnaires had appropriate and analyzable economic data. The data for this research were collected between March and May, 2009.

\section{Stochastic Profit Frontier Function}

Production efficiency is usually analyzed by its two components- technical and allocative. Recent developments combine both measures into one system, which enables more efficient estimates to be obtained by simultaneous estimation of the system [12]. The popular approach to measure efficiency- technical efficiency component -is the use of frontier production function [13]. However, it has been argued that a production function approach to measure efficiency may not be appropriate when farmers face different prices and have different factor endowment [14]. This led to the application of stochastic profit function models to estimate farm specific efficiency directly. 
The profit function approach combines the concepts of technical and allocative efficiencies in the profit relationship, and any errors in the production decision are assumed for to be translated into lower profit or revenue for the producer [15]. Profit efficiency, therefore, is defined as the ability of a farm to achieve the highest possible profit given the prices and levels of fixed factors of that farm, and profit inefficiency in this context is defined as loss of profit for not operating on the frontier [14]. By extension of the stochastic production frontier model, the inefficiency effects can be expressed as a linear function of explanatory variable, reflecting farm-specific characteristics [16]. The advantage of this model is that, it allows the estimation of farm specific efficiency scores and the factors explaining the efficiency differentials among farmers in a single stage estimation procedure. This study utilizes the Battese and Coelli [16] model by postulating a profit function, which is assumed to behave in a manner consistent with the stochastic frontier concept $[3,17,18,19,20]$. The stochastic profit function is defined as

$$
\pi_{i}=f\left(P_{i j}, Z_{k j}\right) \text { Exp.e } e_{i}
$$

Where:

$\pi_{i}=$ normalized profit of the $\mathrm{j}^{\text {th }}$ farm and it is computed as gross revenue less variable cost divided by the farm specific output price, $\mathrm{P}$

$\mathrm{P}_{\mathrm{ij}}=$ price of $\mathrm{j}^{\text {th }}$ variable input faced by the $\mathrm{i}^{\text {th }}$ farm divided by output price

$\mathrm{Z}_{\mathrm{ik}}=$ level of the $\mathrm{k}^{\text {th }}$ fixed factor on the $\mathrm{i}^{\text {th }}$ farm

$\mathrm{e}_{\mathrm{i}}=$ an error term

$\mathrm{i}=1, \ldots \ldots, \mathrm{n}$, is the number of farms in the sample.

The error term $e_{i}$ is assumed to behave in a manner consistent with the frontier concept [17] that is,

$$
e_{i}=V_{i}-U_{i}
$$
$-2$

$\mathrm{V}_{\mathrm{i}}$ is the symmetric error term and it is assumed that it is an independently and identically distributed two-sided error term representing the random effects, measurement errors, omitted explanatory variables and statistical noise, $U_{i}$ is the one-sided error term, representing the inefficiency of the farm.

\section{The Inefficiency Profit Frontier Model}

The inefficiency effects $U_{i}$ in equation 2 is expressed as

$$
U_{i}=\partial_{o}+\sum \partial_{i} Z_{d i}
$$

Where:

$\mathrm{Z}_{\mathrm{i}}=(\mathrm{I} \mathrm{x} \mathrm{m})$ vector of farm specific variables, which varies across respondents and not over time. 
$\partial=(\mathrm{m} \times \mathrm{I})$ vector of unknown coefficients of the farm specific inefficiency variables. The $U_{i}$ is a non-negative one-sided error term representing the inefficiency of the farm. Thus, it represents the profit shortfall from its maximum possible value that will be given by the stochastic frontier.

The estimated frontier function provides an estimate of industry's 'best practice' profit for any given level of price and fixed factors [19].

The method of maximum likelihood was used to estimate the unknown parameters, with the stochastic frontier and the inefficiency models estimated simultaneously. The likelihood function is expressed in terms of the variance parameters,

$$
\sigma^{2}=\sigma^{2}+\sigma_{\mu}^{2}
$$

and $\quad r=\sigma_{\mu}^{2} / \sigma_{\mu}^{2}+\sigma_{v}^{2}$ $-5$

\section{Empirical Specification}

A Cobb-Douglas functional form was selected for this study. This has been used by many empirical studies, particularly those relating to developing countries' agriculture and that the functional forms meet the requirement of being self-dual (allowing an examination of economic efficiency) [20]. In addition, this functional form fits better in cases where there exist high frequencies of observations.

The Cobb-Douglas stochastic profit frontier function is as expressed below:

$\mathrm{LnY}=\beta_{0}+\beta_{1} \operatorname{LnX}_{1}+\beta_{2} \operatorname{LnX}_{2}+\beta_{3} \operatorname{LnX}{ }_{3}+\beta_{4} \operatorname{LnX} X_{4}+\beta_{5} \operatorname{LnX}_{5}+\mathrm{V}_{\mathrm{i}-\mathrm{U}_{\mathrm{i}}-------6}$

Where $\mathrm{Y}=$ Normalised profit (gross margin) in Naira (gross margin divided by output price)

$\mathrm{X}_{1}=$ kilogrammes of catfish raised

$\mathrm{X}_{2}=$ catfish farm size (total are of ponds under catfish production in $\mathrm{m}^{2}$ )

$\mathrm{X}_{3}=$ Normalized cost of feed in Naira (cost of feed divided by output price)

$\mathrm{X}_{4}=$ Normalized cost of fingerlings cultured per culturist per crop

$\mathrm{X}_{5}=$ Normalized cost of hired labour (cost of hired labour divided by output price)

$\beta_{0-} \beta_{5}=$ unknown parameters to be estimated

$\mathrm{V}_{\mathrm{i}}=$ Random error which are assumed to be independently and identically distributed as $\mathrm{N}\left(0, \sigma_{\mathrm{v}}^{2}\right)$

$U_{i}=$ non-negative profit inefficiency effects which are assumed to be half normal (because catfish farmers are assumed rational in their production behavior and hence negative profit is not expected) and independently distributed of $\mathrm{V}_{\mathrm{i}}$.

The presence of technical inefficiency effects were tested using the generalized likelihood ratio test $(\lambda)$, which is defined by

$$
\lambda=-2\left(\mathrm{~L}_{\mathrm{R}}-\mathrm{L}_{\mathrm{U}}\right)
$$

where $L_{R}=\log$ likelihood of the restricted model (Model 1)

$\mathrm{L}_{\mathrm{U}}=\log$ likelihood of the unrestricted model (Model 2) 
$\lambda$ has a chi-square distribution with degree of freedom equal to the number of parameters excluded in the unrestricted model. The null hypothesis was that the restricted Cobb-Douglas profit frontier model is the same as the unrestricted CobbDouglas Stochastic profit model.

\section{The Inefficiency Model}

The $U_{i}$ are the profit inefficiency effects and for this study, they are defined as

$U_{i}=\partial_{0}+\partial_{1} Z_{1}+\partial_{2} Z_{2}+\partial_{3} Z_{3}+\partial_{4} Z_{4}+\partial_{5} Z_{5}+\partial_{6} Z_{6}+\partial_{7} Z_{7}+\partial_{8} Z_{8}+\partial_{9} Z_{9}-----------8$

Where: $\mathrm{Z}_{1}=$ age of catfish farmers in years (expected sign -)

$\mathrm{Z}_{2}=$ years of educational attainment of catfish farmers (expected sign -)

$\mathrm{Z}_{3}=$ farming experience of catfish farmers in years (expected sign -)

$\mathrm{Z}_{4}=$ household size (expected sign -)

$\mathrm{Z}_{5}=$ training on catfish culture (dummy: training $=1$; no training $=0$ ) (expected sign -)

$\mathrm{Z}_{6}=$ Access to credit (dummy: access $=1$, no access $=0$ ) (expected sign - )

$\mathrm{Z}_{7}=$ off-catfish-farm income in Naira(expected sign -)

$\mathrm{Z}_{8}=$ occupational status of farmer (dummy: fulltime $=1$; part-time $=0$ ) (expected sign -)

$\mathrm{Z}_{9}=$ duration of culture in months (expected sign + )

$\partial_{0}, \partial_{1}, \partial_{2}, \partial_{3}, \partial_{4}, \partial_{5}, \partial_{6}, \partial_{7}, \partial_{8}, \partial_{9}=$ parameters to be estimated.

The maximum likelihood estimates of the parameters in the Cobb-Douglas stochastic frontier profit model defined equation 6 , given the specification for profit inefficiency effects defined by equation 8, were obtained using a computer programme, Frontier 4.1, developed by Coelli [21].

The unknown parameters of the models $\beta$ 's and $\partial$ 's and the variance parameter,

$$
\begin{gathered}
\left.\sigma^{2}=\sigma_{\mu}^{2}+\sigma^{2}{ }_{v}{ }^{2}\right) \\
\gamma=\sigma_{\mu}^{2} /\left(\sigma_{\mu}^{2}+\sigma_{v}^{2}\right)
\end{gathered}
$$

were simultaneously estimated.

The value of $y$ above indicates the relative magnitude of the variance, associated with the distribution of the inefficiency effects, $U_{i}$. If $U_{i}$ in the stochastic frontiers are not present or alternatively, if the variance parameter, $\gamma$, associated with the distribution of $U_{i}$ has value zero, then $\sigma^{2}$ u in the frontier model defined by equation 6 is zero and the models reduce to the traditional response model in which the variables age, years of experience, years of schooling, household size, training, access to credit, off-farm income, status and duration of culture are included as explanatory variables in the frontier function (the inefficiency effects are not stochastic).

\section{RESULTS}

The summary of the quantifiable variables in the Cobb-Douglas Stochastic profit frontier model are presented in Table 1 . The result showed an average gross margin of \# 358.70 per kilogramme of catfish raised. The mean output of catfish harvested was 875.76 kilogrammes. The average number of ponds used by the respondents was 3.42. 
Also, the respondents spent more on feeds ( $\$ 124 / \mathrm{kg})$ than other inputs associated with catfish farming. Respondents' ages ranged from 19 to 78 with the mean of 47.25 and were male dominated (89.5\%). The average years of schooling by the farmers were 10.72. Respondents' experiences in catfish farming were on the average 4.63 years, while their mean household size was 6.95 persons. On the average, the respondents obtained $\$ 27254.00$ as receipts from off-catfish-farm activities. Majority of the respondents were part-time catfish farmers (72.7\%), received training (77.6) and had no access to credit (73.4\%) The mean duration of catfish culture was found to be 9.7 months.

Table 3 summarized the result of the maximum likelihood estimates of the parameters in the Cobb-Douglas stochastic profit frontier function (model 2) and the conventional Cobb-Douglas profit model (model 1). The value of the generalized likelihood ratio test was 194.8 and the value of chi-square was 4.57 with 11 degree of freedom. The result of model 2 showed a significant sigma squared (0.23) and gamma (0.99) at 1 percent level. Only the elasticity of catfish output was positive, while that of number of ponds, cost of feeds, cost of fingerlings and cost of hired labour were all negative and statistically significant $(\mathrm{p} \leq 0.10)$ in both models 1 and 2 . Variables in the inefficiency model showed that age of farmer $(-0.40)$, experience $(-0.62)$ and duration of culture $(-1.27)$ were statistically significant $(\mathrm{p} \leq 0.10)$ and negative to profit inefficiency, while years of schooling of the farmer $(0.04)$, training on catfish production (0.42) and off-catfish-farm income (0.06) were statistically significant $(\mathrm{p} \leq 0.10)$ but positive to profit inefficiency. However, the household size, access to credit and status of farmer were not statistically significant at all conventional levels. The profit efficiency of farmers ranged between 0.23 and 0.99 with a mean of 0.84 . Furthermore, 84.7 percent of the respondents had a profit efficiency estimate of 0.70 and above (Table 4).

\section{DISCUSSION}

\section{Summary statistics}

The average quantity of catfish harvested indicates that a moderately high output of catfish is obtained by a catfish farmer in the study area. Analysis of variable costs revealed that feed constitute largest proportion of the total variable cost of catfish production in the study area. The result is in consonance with the findings of Lawal [4] who reported that, the fish feed is the most important component of any fish farm enterprise and it constitutes between 60 and 70 percent of the total recurrent cost of production, which to a large extent determines the viability and profitability of fish farming enterprise. The average profit made per kilogramme of catfish harvested implies that catfish production is highly profitable in the study area. The mean age of 47.25 years indicates that catfish farmers in Benue State are within the active age bracket. The moderately high years of educational attainment by catfish farmers is likely to influence their efficiency in agricultural production in terms of quality and quantity as well as the speed at which they adopt new technology. Majority of the respondents were found to be relatively young in catfish farming as their catfish farming experience 4.6years. This means that aquaculture is relatively new in the study area. Analysis of gender in catfish production indicated that women comprised 10.5 
percent of the respondents. The result implies that catfish production is still primarily a male dominated enterprise. The result of the size of the catfish farmers' household showed an average household size of 6.95 people. This implies that family labour would be readily available when needed in any catfish farming operation. Most of the respondents were part time catfish farmers, suggesting that majority of the farmers had alternative employment. Indeed, average off-farm income of catfish farmers from other activities was found to be high. Though, increased non-farm work is supposed to reduce financial constraints, particularly for resource-poor farmers and thus enables them to purchase productivity enhancing inputs [22]. However, the situation may have negative implication on efficient supervision of farm activities. Furthermore, the high training proportion of farmers means that they are likely to have sound information on marketing and ideas about improved techniques for catfish production. This is likely to make the farmers more efficient. The inadequate access to credit by most catfish farmers is an indication that access to formal credit is a major constraint to farmers in the study area.

\section{Maximum Likelihood Estimates of the Stochastic Profit Frontier Model}

The result showed that there was presence of profit inefficiency effects in catfish farming business in the study. This was confirmed by a test of hypothesis for the presence of inefficiency effects using the generalized Likelihood Ratio $(\lambda)$ test. The result of the $\lambda$ test rejected the hypothesis that restricted Cobb-Douglas profit function (model 1) is the same as the unrestricted Cobb-Douglas stochastic profit function (model 2). This is based on the fact that $\lambda$ value (194.8) was more than the critical value of chi-square (4.57) at 5 percent level of significance with 11 degrees of freedom. This implies that the unrestricted Cobb-Douglas stochastic model which has inefficiency effects fits these data better. Furthermore, the significance $(p \leq 0.05)$ of sigma squared $\left(\sigma^{2}=0.23\right)$ at 1 percent level indicated a good fit and the correctness of the specified distributional assumptions of the model. Also, the estimated value of gamma $(\gamma=0.99)$, which is the ratio of the variance of farm specific profit efficiency to the total variance of the profit, implies that the one-sided random inefficiency component strongly dominates the measurement error. This indicates that about 99 percent of the variation in the actual profit from maximum profit obtainable (profit frontier) among catfish farms was due to the differences in the farmers' practices rather than random variability.

The estimated elasticity parameters of variables with respect to gross profit of catfish farmers revealed the significance of all the independent variables included in the stochastic profit model. However, the elasticity coefficient of number of ponds, cost of feed, cost of fingerlings and cost of hired labour had an inverse relationship with gross profit of the farmers with cost of feed being the most important variable decreasing gross profit of the farmers in the study area. The negative elasticity of number of ponds with respect to farmers' gross profit, was likely due to underutilization of pond capacity. The result further indicated that the quantity of output of catfish produced was the most important variable determining profit in catfish farming in the study area. 


\section{Descriptive Statistics of the Profit Efficiency Estimates}

The summary statistics of farm specific profit efficiencies shown in Table 4 revealed that on the average, farmers operated at a profit efficiency of 0.84 . This implies that the catfish farmers were able to obtain a little above 80 percent of their potential profit from a unit mix of inputs. In other words, about 16 percent of the profit is lost to inefficiency of management. Thus, in the short run, there is a scope for increasing profit from catfish production by 16 percent through the adoption of the technology and the techniques used by the best-practiced catfish farmers.

\section{Determinants of Profit Efficiency}

The signs and significance of the estimated coefficients in the inefficiency model have important implications on the profit efficiency of the farmers. The result revealed that the coefficients of years of schooling, off-catfish-farm income and training were found to increase profit inefficiency. This is contrary to a priori expectation regarding the roles of these factors. The result implies that, these factors led to a decrease in profit efficiency of catfish farmers in the study area. This could be probably because the schooling and training were not directly for the purposes of using the knowledge for fish farming. The negative impact of education on farmers' efficiency was also found by Kareem [5], while analyzing the technical, allocative and economic efficiency of different pond systems in Ogun State, Nigeria.

Also, the positive impact of off-catfish-farm income of farmers on profit inefficiency suggests that farmers who are involved in other income generating activities are not re-investing the proceeds of such activities into catfish farm. This was also reported by Singh et al.[6].

The negative and significant coefficient of age of farmer, years farming experience and duration of culture imply that increase in these variables increased profit efficiency in the study area. The result on farming experience is expected since farming experience is expected to correlate positively with adoption of improved technology and techniques of productions for efficient production and profit maximization. This result confirmed the findings of Kolawole [3], Kareem [5] and Adeleke [19] but contrary to the work of Singh et al.[6]. Furthermore, the positive relation between duration of catfish culture and efficiency of profit making is likely due to the fact that when fish is allowed to grow over time with proper feeding, it gains more weight and this could translate into higher receipts from sales since catfish is sold in kilogrammes in the study area.

\section{CONCLUSION}

The study used stochastic profit frontier function to analyze the efficiency of sampled catfish farmers in Benue State. Using detailed data from a structured questionnaire, the study showed that profit efficiency varied widely among the sampled farmers. It ranged from 23 percent to 99 percent with a mean of 84 percent. The mean level of profit efficiency indicates that there exists room to increase profit by improving technical and allocative efficiency. The variables of years of schooling of farmers, off-catfish-farm income and training decreased profit efficiency while age of farmers, 


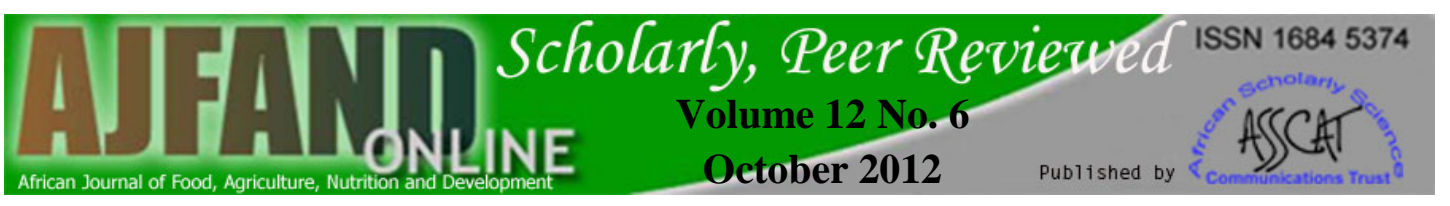

years of catfish farming experience and duration of culture increased efficiency in profit making. The policy implication of these findings is that profit inefficiency in catfish production can be reduced significantly overtime as the farmers get more experienced. Furthermore, a more conducive environment needs to be created to encourage aged farmers to be involved in catfish production in a bid to alleviate poverty and food insecurity in the state and the country at large. Also catfish farming in the area is male dominated. Therefore, females should be encouraged to participate in catfish farming in the area as a means of augmenting their income and improving their standard of living. 


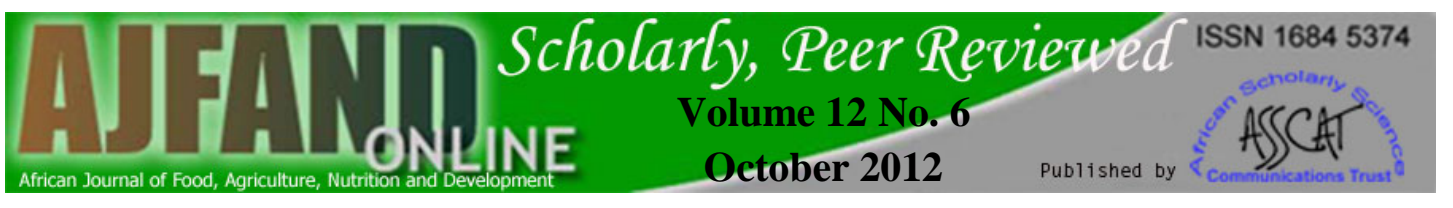

Table 1: Summary Statistics for the Variables in the Cobb- Douglas Stochastic Frontier Profit Model for Catfish Farming in Benue State

\begin{tabular}{|c|c|c|c|c|}
\hline Variable & Mean & $\begin{array}{l}\text { Standard } \\
\text { deviation }\end{array}$ & Minimum & Maximum \\
\hline Gross margin( $\$ / \mathrm{kg})$ & 358.70 & 206.85 & 42.50 & 1291.26 \\
\hline 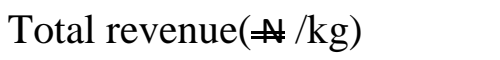 & 598.43 & 228.17 & 175.00 & 1500.00 \\
\hline Catfish output(Kg) & 875.76 & 1862.43 & 25.00 & 15000.00 \\
\hline Number of ponds & 3.42 & 3.49 & 1.00 & 25.00 \\
\hline Cost of feeds( $\# / \mathrm{kg})$ & 124.03 & 86.10 & 16.39 & 20000.00 \\
\hline Cost of fingerlings $(\mathbb{N} / \mathrm{kg})$ & 49.35 & 35.06 & 9.42 & 333.33 \\
\hline Cost of hired labour( $\# / k g)$ & 9.57 & 33.20 & 0.00 & 255.32 \\
\hline Age(years) & 47.25 & 12.53 & 19.00 & 78.00 \\
\hline Level of education(years) & 10.72 & 5.55 & 0.00 & 22.00 \\
\hline Farming experience(years) & 4.63 & 2.73 & 1.00 & 15.00 \\
\hline Household size & 6.95 & 4.22 & 1.00 & 35.00 \\
\hline Off-catfish-farm income( $\mathbb{\#}$ ) & 27254 & 62043.55 & 1000 & 500000.00 \\
\hline Duration of culture(Months) & 9.7 & 3.00 & 3.00 & 24 \\
\hline
\end{tabular}

\# =Nigerian currency, Naira

$\mathrm{Kg}=$ kilogramme 


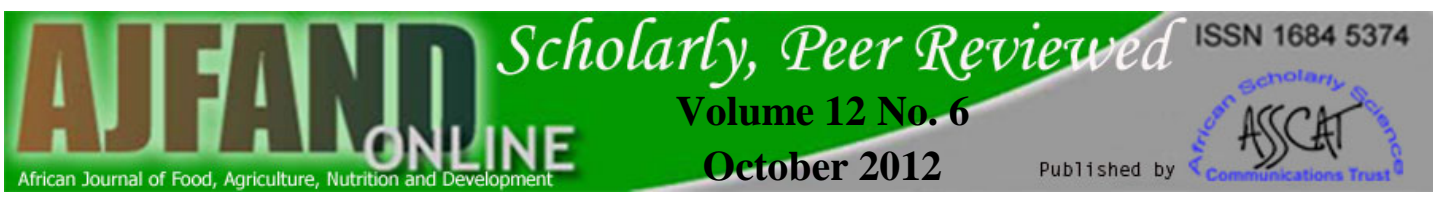

Table 2: Frequency Distribution of the Socio-economic Characteristics of Catfish Farmers in Benue State

\begin{tabular}{|c|c|c|}
\hline Index & Frequency & Percentage \\
\hline \multicolumn{3}{|l|}{ Age (years) } \\
\hline$\leq 20$ & 3 & 21.0 \\
\hline $21-40$ & 45 & 31.5 \\
\hline $41-60$ & 77 & 53.8 \\
\hline$\geq 60$ & 18 & 12.6 \\
\hline Total & 143 & 100.0 \\
\hline Mean & 47.0 & \\
\hline \multicolumn{3}{|l|}{ Sex } \\
\hline Female & 15 & 10.5 \\
\hline Male & 128 & 89.5 \\
\hline Total & 143 & 100.0 \\
\hline \multicolumn{3}{|c|}{ Education (years) } \\
\hline 0 & 16 & 11.2 \\
\hline $1-6$ & 26 & 18.1 \\
\hline $7-12$ & 49 & 34.3 \\
\hline$>12$ & 52 & 36.4 \\
\hline Total & 143 & 100.0 \\
\hline Mean & 10.7 & \\
\hline \multicolumn{3}{|c|}{ Farming experience (years) } \\
\hline $1-5$ & 118 & 82.5 \\
\hline $6-10$ & 23 & 16.1 \\
\hline$>10$ & 2 & 1.4 \\
\hline Total & 143 & 100.0 \\
\hline Mean & 4.6 & \\
\hline \multicolumn{3}{|c|}{ Household size } \\
\hline $1-5$ & 55 & 38,5 \\
\hline $6-10$ & 69 & 48.3 \\
\hline$>10$ & 19 & 13.3 \\
\hline Total & 143 & 100.0 \\
\hline Mean & 6.9 & \\
\hline \multicolumn{3}{|c|}{ Status of farmer } \\
\hline Full time & 39 & 27.3 \\
\hline Part time & 104 & 72.7 \\
\hline Total & 143 & 100.0 \\
\hline \multicolumn{3}{|c|}{ Training in catfish culture } \\
\hline Trained & 111 & 77.6 \\
\hline Not trained & 32 & 22.4 \\
\hline Total & 143 & 100.0 \\
\hline \multicolumn{3}{|c|}{ Access to formal credit } \\
\hline Access & 38 & 26.6 \\
\hline No access & 105 & 73.4 \\
\hline Total & 143 & 100.0 \\
\hline
\end{tabular}


Table 3: Maximum Likelihood Estimate of the Parameters in Cobb-Douglas Stochastic Frontier Profit Function Model for Catfish Farmers in Benue State

\begin{tabular}{|c|c|c|}
\hline Variable & Model 1 & Model 2 \\
\hline \multicolumn{3}{|l|}{ Stochastic Frontier Profit Model } \\
\hline Constant & $\begin{array}{l}-1.74 * * \\
(-11.26)\end{array}$ & $\begin{array}{l}-1.11^{* *} \\
(82.07)\end{array}$ \\
\hline LnCatfish output(kg) & $\begin{array}{l}1.59 * * \\
(28.03)\end{array}$ & $\begin{array}{l}1.42 * * \\
(82.07)\end{array}$ \\
\hline LnNumber of ponds & $\begin{array}{l}-0.07 * * * \\
(-1.62)\end{array}$ & $\begin{array}{l}-0.02 * * * \\
(-1.68)\end{array}$ \\
\hline LnCost of Feeds( $/ \mathrm{kg})$ & $\begin{array}{l}-0.37 * * \\
(-9.55)\end{array}$ & $\begin{array}{l}-0.30 * * \\
(-20.56)\end{array}$ \\
\hline LnCost of fingerlings( $(\mathrm{kg})$ & $\begin{array}{l}-0.13^{* *} \\
(-3.70)\end{array}$ & $\begin{array}{l}-0.11^{* *} \\
(-9.12)\end{array}$ \\
\hline LnCost of hired labour( $/ \mathrm{kg})$ & $\begin{array}{l}-0.02^{*} \\
(-2.12)\end{array}$ & $\begin{array}{l}-0.001 * * * \\
(-1.86)\end{array}$ \\
\hline \multicolumn{3}{|l|}{ Inefficiency Model } \\
\hline Constant & - & $\begin{array}{l}3.36^{* *} \\
(3.44)\end{array}$ \\
\hline LnAge (years) & - & $\begin{array}{l}-0.40^{* * *} \\
(-1.52)\end{array}$ \\
\hline LnYears of schooling & - & $\begin{array}{l}0.04^{* * * *} \\
(1.00)\end{array}$ \\
\hline LnFarming experience(years) & - & $\begin{array}{l}-0.62 * * \\
(-6.00)\end{array}$ \\
\hline LnHousehold size & - & $\begin{array}{l}-0.04 \\
(0.36)\end{array}$ \\
\hline Training & - & $\begin{array}{l}0.42^{*} \\
(2.84)\end{array}$ \\
\hline Access to credit & - & $\begin{array}{l}-0.10 \\
(-0.69)\end{array}$ \\
\hline LnOff-catfish-farm income( $)$ & - & $\begin{array}{l}0.06 * * \\
(4.37)\end{array}$ \\
\hline Status of farmer & - & $\begin{array}{l}0.56 \\
(0.55)\end{array}$ \\
\hline LnDuration of culture(Months) & - & $\begin{array}{l}-1.27 * * \\
(-8.01)\end{array}$ \\
\hline Sigma squared $\left(\sigma^{2}=\sigma_{v}^{2}+\sigma^{2}{ }_{u}\right)$ & 0.06 & $\begin{array}{l}0.23^{* *} \\
(9.78)\end{array}$ \\
\hline $\operatorname{Gamma}\left(\gamma=\sigma_{\mathrm{u}}^{2} / \sigma_{\mathrm{v}}^{2}+\sigma_{\mathrm{u}}^{2}\right)$ & - & $\begin{array}{l}0.99 * * \\
(1575288.90)\end{array}$ \\
\hline Log Likehood Estimate & 1.30 & 98.70 \\
\hline
\end{tabular}

$* *, *, * *=$ t-ratio significant at $1 \%, 5 \%$ and $10 \%$ level respectively Values in parenthesis represent t-test

$\mathrm{Ln}=$ Natural log to base two and $\#$ = Nigerian currency, Naira 


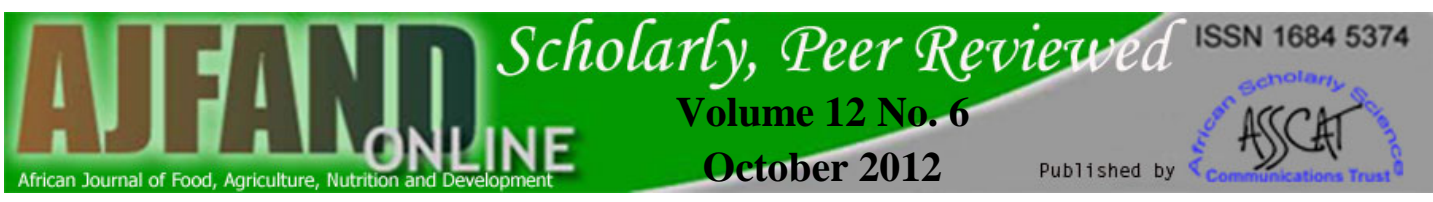

Table 4: Distribution of Profit Efficiency estimates from Cobb-Douglas Stochastic Frontier Model of Catfish Farmers in Benue State

\begin{tabular}{lll}
\hline Efficiency Range & Frequency & Percentage \\
\hline $0.10-0.29$ & 2 & 1.4 \\
$0.30-0.49$ & 6 & 4.2 \\
$0.50-0.69$ & 14 & 9.8 \\
$0.70-0.89$ & 59 & 41.3 \\
$0.90-0.99$ & 62 & 43.4 \\
Total & $\mathbf{1 4 3}$ & $\mathbf{1 0 0 . 0}$ \\
Mean efficiency & $\mathbf{0 . 8 4}$ & \\
Minimum & $\mathbf{0 . 2 3}$ & \\
Maximum & $\mathbf{0 . 9 9}$ & \\
\hline
\end{tabular}




\section{REFERENCES}

1. Olagunju FI, Adesiyan IO and AA Ezekiel Economic viability of catfish production in Oyo State. Nigeria J. of Human Eco. 2007; 21(2):121-124.

2. Oguntola $\mathbf{S}$ How to achieve profitable fish farming in Nigeria. Nigerian Tribune Newspaper Wednesday 20 February 2008 www.tribune.com.ng/20022008/agric.html.

3. Kolawole O Determinants of profit efficiency among small scale rice farmers in Nigeria: A Profit Function Approach. Research J. of Applied Sc. 2006; 1(14): $116-122$.

4. Lawal W L Economic Analysis of fish culture in Benue state. PhD thesis submitted to the department of agricultural economics university of agriculture Makurdi, Nigeria. 2001:174 pp.

5. Kareem RO, Dipeolu AO, Aromolan AB and Akegbejo-Samson Analysis of technical, allocative and economic efficiency of different pond systems in Ogun State Nigeria. African J. of Agric Research, 2008; 3(4): 246-254.

6. Singh K, Dey MM, Rabbani AG, Sudhakaran PO and G Thapa Technical efficiency of freshwater aquaculture and its determinants in Tripura, India. Agricutural Research Review, 2009; 22: 185-195.

7. Ioni OE Allocative efficiency in pond fish production in Delta State: A production function approach. Agricutura Tropica et Subtropica, 2007; 40(4): 127-134.

8. Ekunwe PA and CO Emokaro Technical efficiency of catfish farmers in Kaduna State. J of Applied Sc and Research, 2009; 5(7): 802-805.

9. Adewuyi SA, Phillip BB, Ayinde IA and D Akerele Analysis of profitability of fish farming in Ogun State Nigeria, J Hum Ecol, 31(3): 179-184.

10. Kudi TM, Baka FP and TK Atala Economics of fish production in Kaduna State Nigeria. ARPN J of Agric and Bio Sc, 2008; 5(5\&6): 17-21.

11. BNARDA. Inventory of aquatic resources in Benue State. Benue Agriculture and Rural Development Authority. 2003:3-17.

12. Wang $\mathbf{J}$, Cramer $\mathbf{G L}$ and $\mathbf{E} \mathbf{J}$ Wailes Production efficiency of Chinese agriculture: Evidence from rural household survey data. Agricultural Economics, 1996; 15: 17-28.

13. Trouvelekas V, Pantzions CJ and C Fotopoulos Technical Efficiency of Alternative Farming Systems: The case of Greek Organic and Conventional Olive Growing Farms. Food Policy, 2001; 26: 549-569. 


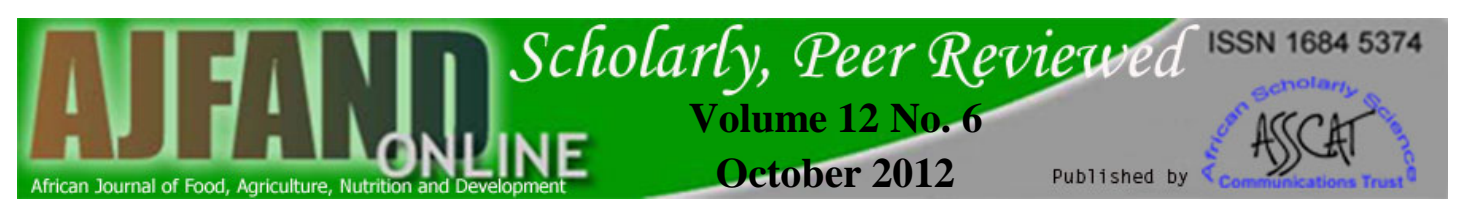

14. Ali $\mathbf{M}$ and JC Flinn Profit Efficiency among Basmati rice producers in Pakistan Punjab. American J. of Agric. Economics, 1989; 71: 303-310.

15. Ojo S O Productivity and technical efficiency of poultry egg production in Nigeria. International J. of Poultry Sc. 2003; 2: 459 - 464.

16. Battese $\mathbf{G}$ and $\mathbf{T}$ Coelli A Model for Technical Inefficiency Effects in a Stochastic Frontier Production Function for Panel Data. Empirical Economics, 1995; 20:325-332.

17. Rahman S Profit Efficiency among Bangladeshi Rice Farmers. School of Economic Studies, The University of Manchester, Manchester, England, UK. 2002.

18. Tijani AA, Alimi $\mathbf{T}$ and AT Adesiyan Profit efficiency among Nigerian poultry egg farmers: A case study of Aiyedoto farm settlement, Nigeria. Research J. of Agric. and Bio. Sc. 2006; 2(6):256-261.

19. Adeleke OA Profit Efficiency among Female Smallholder Farmers in Atiba Local Government Area of Oyo State. J. of Economic Theory, 2008; 2(3):7783.

20. Ogundari K, Ojo SO and B Brummer Productivity potential and technical efficiency of aquaculture production in alleviating poverty. Emperical Evidence from Nigeria J. of Fisheries International, 2006; 1(1-2):21-26.

21. Coelli TJ A guide to Frontier Version 4.1: A computer programme for Stochastic Frontier Production and Cost Function Estimation. Department of Econometrics, University of New England, Armidale, Australia. 1994.

22. Huffman WE Farm and off farm decisions: the role of human capital. Review of economics and statistics, 1980; 62:14-23. 